\title{
The contribution of marine organics to the air quality of the western United States
}

\author{
B. Gantt ${ }^{1}$, N. Meskhidze ${ }^{1}$, and A. G. Carlton ${ }^{2}$ \\ ${ }^{1}$ Department of Marine, Earth, and Atmospheric Sciences North Carolina State University, Raleigh, NC, USA \\ ${ }^{2}$ Office of Research and Development, National Exposure Research Laboratory Environmental Protection Agency, \\ RTP, NC, USA
}

Received: 24 February 2010 - Published in Atmos. Chem. Phys. Discuss.: 8 March 2010

Revised: 19 June 2010 - Accepted: 16 July 2010 - Published: 9 August 2010

\begin{abstract}
The contribution of marine organic emissions to the air quality in coastal areas of the western United States is studied using the latest version of the US Environmental Protection Agency (EPA) regional-scale Community Multiscale Air Quality (CMAQv4.7) modeling system. Emissions of marine isoprene, monoterpenes, and primary organic matter (POM) from the ocean are implemented into the model to provide a comprehensive view of the connection between ocean biology and atmospheric chemistry and air pollution. Model simulations show that marine organics can increase the concentration of $\mathrm{PM}_{2.5}$ by $0.1-0.3 \mu \mathrm{g} \mathrm{m}^{-3}$ (up to $5 \%$ ) in some coastal cities such as San Francisco, CA. This increase in the $\mathrm{PM}_{2.5}$ concentration is primarily attributed to the POM emissions, with small contributions from the marine isoprene and monoterpenes. When marine organic emissions are included, organic carbon (OC) concentrations over the remote ocean are increased by up to $50 \%$ (25\% in coastal areas), values consistent with recent observational findings. This study is the first to quantify the air quality impacts from marine POM and monoterpenes for the United States, and it highlights the need for inclusion of marine organic emissions in air quality models.
\end{abstract}

\section{Introduction}

Several studies have shown that marine emissions of biogenic volatile organic compounds (BVOCs) and primary organic aerosols have the potential to affect coastal air quality (O'Dowd et al., 2004; Liakakou et al., 2007; Gantt et al., 2010). Observations of aerosol composition show that these emissions, which include both biogenic trace gases and par-

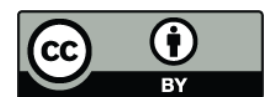

Correspondence to: N. Meskhidze (nmeskhidze@ncsu.edu) ticles, are strongly tied to the seasonal cycles in ocean biology (O'Dowd et al., 2004). Organic aerosols in the marine boundary layer are proposed to have different sources that can be broadly classified as primary, e.g., derived from the mechanical process of bubble bursting, and secondary, derived through ocean emission of BVOCs followed by chemical reaction and subsequent condensation of products into the aerosol phase (Ceburnis et al., 2008; Sellegri et al., 2008). Starting with several contributions of Blanchard and Woodcock in the 1950s (e.g., Blanchard and Woodcock, 1957 and references therein), the bursting of bubbles entrained in ocean waters has been understood to present a significant source of primary organic matter (POM). Since then a large body of work, recently reviewed in great detail by Lewis and Schwartz (2004), has contributed to our understanding of the microphysical aerosol production mechanisms, aerosol mass and number fluxes, aerosol size distributions, aerosol chemical composition and the relationship of these with respect to wind speed, seawater temperature, ambient relative humidity and seawater composition in the bulk and at the surface. Many organic compounds accumulate at the seawater/air interface, either due to their low solubility or active transport by sub-millimeter size bubbles to the surface. Bubbles that burst in the presence of the microlayer can become considerably enriched with organic compounds in the aerosol relative to bulk seawater concentrations (Hoffman and Duce, 1976; Donaldson and Vaida, 2006) which is often observed over the productive waters of the ocean (O'Dowd et al., 2004; Facchini et al., 2008a). The observed chemical compositions of marine-derived organic compounds are diverse, containing exopolymer secretions (Bigg, 2007; Bigg and Leck, 2008; Leck and Bigg, 2008), oxygenated carbohydrate-like molecules (Hawkins et al., 2010; Russell et al., 2010), and alkylamonium salts (Facchini et al., 2008b) that are water insoluble in some (O'Dowd et al., 2004; Sciare et al., 2009) but not all cases reported so far (Facchini et al., 2008; Rinaldi

Published by Copernicus Publications on behalf of the European Geosciences Union. 
et al., 2010). Since organic carbon enrichment of marine aerosols generally increases with decreases in aerosol size (Keene et al., 2007; Facchini et al., 2008a), such aerosols can be easily transported to the coastal areas, contributing to the organic aerosol load.

Production of secondary organic aerosols (SOA) from phytoplankton-generated reactive trace gases is a topic of considerable debates in the recent literature. Formation of SOA with a marine source begins with the oxidation of BVOCs emitted by phytoplankton. After oxidation through gas and aqueous-phase reactions, the lower volatility products can condense on pre-existing particles or form new particles over marine areas (O'Dowd et al., 2007 and references therein). Several VOCs with the potential to form aerosols have been measured in the marine boundary layer, including dimethyl sulfide (DMS), iodine species, isoprene, monoterpenes, and amines (Shaw et al., 1983; O'Dowd et al., 2002; Bonsang et al., 1992; Yassaa et al., 2008; Facchini et al., 2008b). Currently, "bottom-up" and "top-down" global estimates of oceanic emissions of isoprene and $\alpha$ pinene differ by over a factor of 30 and 2000, respectively (Luo and Yu, 2010). Simulations suggest that the oceanic $\alpha$ pinene emission based on the bottom-up value has little effect on OC aerosol formation; however, emissions derived from the top-down approach can enhance the zonally-averaged total condensable secondary organic matter by more than $100 \mathrm{n} \mathrm{C} \mathrm{m}^{-3}$ in the lower troposphere of the Southern Hemisphere $\left(40^{\circ} \mathrm{S}-60^{\circ} \mathrm{S}\right)$ (Luo and $\left.\mathrm{Yu}, 2010\right)$. Due to such large uncertainty, the contribution of marine isoprene and monoterpenes to $\mathrm{OC}$ aerosol concentrations are examined in this study.

Several recent studies have implemented emission of marine isoprene and primary organic aerosols into 3dimensional photochemical models to determine the air quality impacts. O'Dowd et al. (2008) implemented North Atlantic primary emissions into the REMOTE climate model by using a relationship between the organic fraction of submicron sea spray and $[\mathrm{Chl}-a]$. The model-predicted aerosol concentration of between $0.2-0.3 \mu \mathrm{g} \mathrm{m}^{-3}$ were similar to observations at Mace Head, Ireland, for both the summer and winter months. Marine isoprene emissions were implemented in the Community Multiscale Air Quality (CMAQ) model to determine the impacts on air quality in the United States (Gantt et al., 2010). They show that marine isoprene can add up to $0.004 \mu \mathrm{g} \mathrm{m}^{-3}$ to the SOA concentration in coastal areas, a minor contribution $(<0.5 \%)$ when compared to the terrestrial sources (Gantt et al., 2010). The effect of marine isoprene on ozone $\left(\mathrm{O}_{3}\right)$ formation in urban coastal areas was also small, with enhancement of maximum 8-h average $\mathrm{O}_{3}$ only by $0.2 \mathrm{ppb}$. In this study, we expand upon Gantt et al. (2010) by examining the impact of both POM and SOA from marine sources on the air quality of the western US.

\section{Method}

\subsection{CMAQ model description}

We have conducted three summertime (June-August) simulations with CMAQ model (Version 4.7) using a $12 \times 12 \mathrm{~km}^{2}$ spatial resolution in a domain comprising the western US and parts of the Pacific Ocean. The model simulations are conducted using meteorological data generated offline by the Pennsylvania State University/National Center for Atmospheric Research Mesoscale Modeling System Generation 5 (MM5) version 3.7.4 (Grell et al., 1994). Simulations start on 1 June 2005 using the initial conditions from the 31 May output from year-long CMAQ simulations performed by the EPA. The boundary conditions are set every hour from a global chemical transport model, the Goddard Earth Observing System (GEOS)-Chem (Park et al., 2004). Emissions of anthropogenic gaseous and aerosol species are based on the 2005 National Emissions Inventory (NEI) version 1, while biogenic emissions are based on the Biogenic Emissions Inventory System (BEIS) version 3.13. Gas-phase chemistry is computed using the Carbon-Bond Mechanism version 5 (CB05) reactions, with SOA formation simulated using an advanced module including processes such as acid catylization, oligomerization, and in-cloud processing (Carlton et al., 2010).

Using this model configuration, three different summertime simulations were performed. The first is a baseline simulation in which no marine emissions are added. The second, referred hereto as the bottom-up simulation, includes emissions of marine isoprene based on laboratory measurements of Gantt et al. (2009) and marine POM based on O'Dowd et al. (2008). Marine monoterpenes were not included in bottom-up simulations due to the lack of well established and constrained laboratory-based emission rates (Yassaa et al., 2008; Luo and Yu, 2010). The third simulation, referred as the top-down, is similar to the bottom-up approach except both marine isoprene and monoterpene emissions are calculated based on marine boundary layer (MBL) concentration measurements reported for the Southern Ocean (Colomb et al., 2009). Marine monoterpenes are included in the topdown approach due to reported ambient concentrations comparable to phytoplankton-produced isoprene (Yassaa et al., 2008; Colomb et al., 2009). A detailed description of the method used to create these emissions is found in Sects. 2.2 and 2.3. The summertime period of this model simulation was chosen due to the high solar radiation which potentially results in the highest emissions of marine BVOCs and rapid photochemistry.

The selected model domain includes nearly the entire coastal upwelling region; therefore it is well suited to study the impact of marine organic emissions on air quality in the western United States. However, outside this area, boundary conditions that are derived from outputs of global models did not include marine OC aerosol and trace gas emissions. Due 
to relatively close $(\sim 150 \mathrm{~km})$ proximity of some parts of the coast to the model boundary, we have carefully examined the effects of boundary conditions on marine primary and secondary aerosol concentration. Over the western portion of our model area it was found that surface concentrations of marine aerosols in grid cells directly adjacent to the domain boundary were over $80 \%$ of the average background concentration. Furthermore, the sharp concentration gradients of marine aerosols (between ocean and terrestrial areas, for example) were much smaller ( $\sim 2-3$ grid cells) than the distance from the domain boundary to the coast ( $>12$ grid cells). Therefore, the boundary conditions are expected to have minor effect on the surface concentration of aerosols and ozone over the coastal US.

\subsection{Marine VOC emissions}

In both the bottom-up and top-down simulations, marine VOC emissions were added offline to the existing terrestrial emissions files. For the bottom-up simulations, marine isoprene emissions were created based on laboratory measurements of isoprene production from diatoms under a range of light conditions from Gantt et al. (2009). Diatoms were chosen in this study because they are one of the dominant summer phytoplankton classes for Pacific coast of the US (Chavez et al., 1991), despite considerable variation in species dominance with latitude and seasonality. The creation and implementation of marine isoprene emissions followed the same method of Gantt et al. (2010), with the main difference being the use of monthly-averaged Level 3 MODIS/Aqua-derived [Chl- $a$ ] and $k_{490}$ coefficient at $\sim 4 \mathrm{~km}$ resolution for the three months of simulations. These data were regridded to the $12 \times 12 \mathrm{~km}^{2}$ spatial resolution and projected into the Lambert Conformal Conic coordinates of the model domain. The ambient solar radiation, $10 \mathrm{~m}$ winds, and skin temperature (a proxy for sea surface temperature (SST)) were obtained from the MM5 meteorological fields to calculate the emission rates. Detailed description of the bottom-up marine isoprene emission calculations and implementation into the CMAQ model are given in Gantt et al. (2009) and (2010), respectively.

Marine isoprene and monoterpene emissions in our topdown approach are based on average surface concentration measurements of Colomb et al. (2009) in the remote MBL of the Southern Indian Ocean using a method similar to Luo and $\mathrm{Yu}$ (2010). In this approach, surface VOC concentration measurements from a region of maximum biological activity and little influence from terrestrial emissions are used to estimate the surface fluxes. The averaged VOC emissions over the Southern Indian Ocean (normalized by chlorophyll abundance, surface wind speed and SST) are then used to calculate marine isoprene and monoterpene emissions over the model domain. The emissions of marine isoprene and monoterpenes are estimated using the following equation of Guenther et al. (1996), suggested for terrestrial isoprene emissions calculations: $E_{\mathrm{SIO}}=C \cdot H \cdot \tau^{-1}$. In this formulation, $E_{\mathrm{SIO}}$ is the emission rate (molecules $\mathrm{cm}^{-2} \mathrm{~s}^{-1}$ ) at the Southern Indian Ocean site, $C$ is the average MBL concentration (molecules $\mathrm{cm}^{-3}$ ), $H$ is the MBL height $(\mathrm{cm})$, and $\tau$ is the lifetime of the gas (sec). We assume a $\tau$ of $2 \mathrm{hr}$ $(7200 \mathrm{sec})$ for isoprene and $3.75 \mathrm{~h}(13500 \mathrm{~s})$ for monoterpenes, values adapted from Atkinson and Arey (1998) and Galbally et al. (2007). The lifetime of monoterpenes is based on the lifetime of $\alpha$-pinene, the most common monoterpene measured in the MBL (Yassaa et al., 2008). Because Colomb et al. (2009) report the surface VOC concentrations and meteorological/ocean measurements as $\sim 12$-h averages over the surface ocean waters of variable biological productivity, the flux footprint is very complex and hard to interpret. $\mathrm{Pa}-$ rameters affecting VOC emission rates/ambient concentrations such as phytoplankton abundance and speciation, surface solar radiation, and wind speed/direction are not well constrained. The very short atmospheric lifetime of isoprene also leads to strongly decaying vertical mixing ratios that further complicate emission rate calculations. As a result of these uncertainties, to convert the reported surface concentrations to $C$ values used in the above equation, we employ MBL vertical profiles of isoprene predicted by the bottom-up CMAQ simulation in remote ocean regions off the coast of Baja California, northern California, and Washington. Isoprene and monoterpene emissions derived for the Southern Indian Ocean are then normalized by gas exchange coefficients and $[\mathrm{Chl}-a]$ values and applied to the CMAQ domain. The emission rate in CMAQ $\left(E_{\mathrm{CMAQ}}\right)$ can be calculated using the following equation:

$E_{\mathrm{CMAQ}}=\frac{k_{\mathrm{CMAQ}}}{k_{\mathrm{SIO}}} \cdot E_{\mathrm{SIO}} \cdot \frac{[\mathrm{Chl}-\alpha]_{\mathrm{CMAQ}}}{[\mathrm{Chl}-\alpha]_{\mathrm{SIO}}} \cdot S A$

where $E_{\mathrm{CMAQ}}$ is in units of moles s${ }^{-1}, S A$ denotes $12 \times 12 \mathrm{~km}^{2} \mathrm{CMAQ}$ grid, $k_{\mathrm{SIO}}, k_{\mathrm{CMAQ}}$ and [Chl- $\left.a\right]_{\mathrm{SIO}}$, [Chl$a]_{\mathrm{CMAQ}}$ are the gas exchange coefficients $\left(\mathrm{m} \mathrm{s}^{-1}\right)$ and surface chlorophyll concentration $\left(\mathrm{mg} \mathrm{m}^{-3}\right)$ at the Southern Indian Ocean measurement site and CMAQ domain, respectively. The gas exchange coefficient is given by the equation: $k=0.31 U_{10}^{2} \cdot\left(\frac{660}{S c}^{0.5}\right.$ ) (Wanninkhof, 1992), with $U_{10}$ taken from the measurements of Colomb et al. (2009) and the MM5 hourly $10 \mathrm{~m}$ wind speed for Southern Indian Ocean and CMAQ domain, respectively. Schmidt number $(S c)$ is calculated using De Bruyn and Saltzman (1997) formulation.

\subsection{Marine Primary Organic Emissions}

Emissions of marine primary organic aerosols were added to the model online in both the bottom-up and top-down simulations. The emission rate of marine primary organic aerosols was determined using the relationship between $[\mathrm{Chl}-a]$ and the sub-micron organic mass fraction of sea spray mass concentration from O'Dowd et al. (2008). The marine primary organic aerosol emissions in CMAQ are added to the existing Aitken ( $0.1 \%$ by mass) and accumulation mode $(99.9 \%$ 
Table 1. Comparison between simulated and observed organic carbon aerosol concentrations for two coastal IMPROVE stations during the simulation period and the period from 1 June to 15 July 2005.

\begin{tabular}{|c|c|c|c|c|c|c|c|}
\hline \multirow{2}{*}{ Station } & \multicolumn{2}{|c|}{ Mean Obs. $\left(\mu \mathrm{g} \mathrm{m}^{-3}\right)$} & \multirow{2}{*}{ Simulation } & \multicolumn{2}{|c|}{ Mean Sim. $\left(\mu \mathrm{g} \mathrm{m}^{-3}\right)$} & \multicolumn{2}{|c|}{ Correlation Coefficient } \\
\hline & 1 June to 31 Aug & 1 June to 15 July & & 1 June to $31 \mathrm{Aug}$ & 1 June to 15 July & 1 June-31 to Aug & 1 June to 15 July \\
\hline \multirow[t]{3}{*}{ Point Reyes, CA } & 0.57 & 0.38 & Baseline & 0.63 & 0.15 & -0.10 & 0.07 \\
\hline & & & Bottom-up & 0.80 & 0.35 & -0.10 & -0.01 \\
\hline & & & Top-down & 0.80 & 0.36 & -0.10 & -0.01 \\
\hline \multirow{3}{*}{ Redwood NP, CA } & 0.44 & 0.37 & Baseline & 1.49 & 0.20 & 0.20 & 0.80 \\
\hline & & & Bottom-up & 1.68 & 0.35 & 0.22 & 0.89 \\
\hline & & & Top-down & 1.69 & 0.36 & 0.22 & 0.89 \\
\hline
\end{tabular}

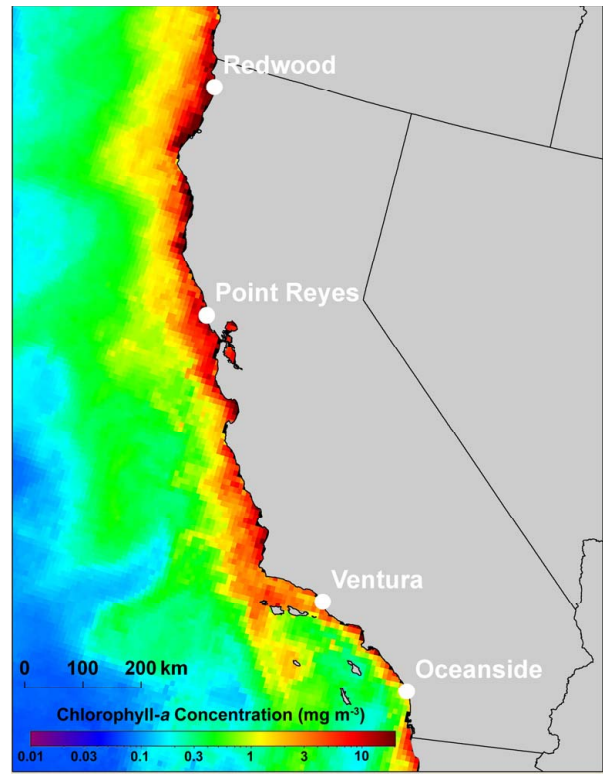

Fig. 1. Locations of the IMPROVE and PAMS stations used in this study and the seasonally-averaged chlorophyll- $a$ concentrations for the summer of 2005 .

by mass) primary organic carbon emissions, which were previously restricted exclusively to terrestrial regions. Using the sub-micron sea spray function to calculate the organic fraction of the CMAQ accumulation mode sea spray mass is justified, as the majority of the CMAQ accumulation mode particle mass is less than $1 \mu \mathrm{m}$ in diameter. The [Chl- $a$ ] for each model grid is determined from the monthly-averaged Level 3 MODIS/Aqua-derived [Chl- $a$ ], and the sea spray mass emissions are calculated from the existing accumulation mode CMAQ sea salt emissions. The CMAQ sea salt fluxes are driven by the MM5 meteorological variables using the GongMonahan (Gong, 2003) and the deLeeuw (deLeeuw et al., 2000) emission functions for the open ocean and the surf zone, respectively. A complete description of the sea salt emission model in this version of CMAQ, including relative humidity and white cap coverage dependence, is found in Kelly et al. (2009). The sea salt emissions were converted
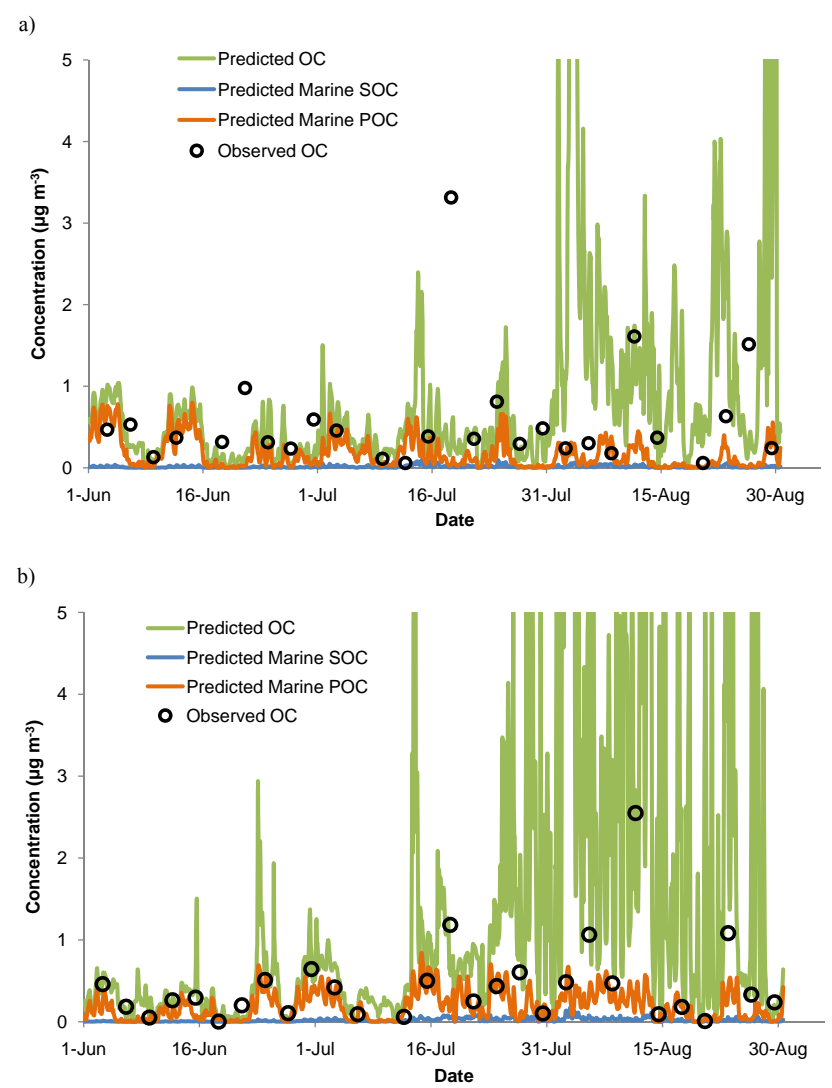

Fig. 2. Time series of hourly top-down model-predicted surface $\mathrm{OC}_{2.5}$, marine primary and secondary $\mathrm{OC}_{2.5}$ and 24-h average observed $\mathrm{OC}_{2.5}$ for the (a) Point Reyes and (b) Redwood IMPROVE sites. The concentration values above $5 \mu \mathrm{g} \mathrm{m}^{-3}$ are not shown.

into sea spray emissions by calculating the apparent density of the sea spray aerosol as a function of organic fraction. In the model results, the sum of the Aitken and accumulation mode constitutes particles with an aerodynamic diameter less than $2.5 \mu \mathrm{m}$. For model-predicted changes in $\mathrm{OC}_{2.5}$ concentrations due to marine organics, an OM/OC mass ratio of 1.4 is used for marine primary organic aerosols (Decesari et al., 2007). 


\section{Results}

\subsection{Comparison with observations}

To test the effect of the marine emissions on model-predicted atmospheric concentrations of $\mathrm{OC}$, the simulated values were compared to ambient measurements at several different monitoring stations on the coast of California. OC concentration observations were obtained from Point Reyes National Seashore $\left(38.12^{\circ} \mathrm{N}, 122.91^{\circ} \mathrm{W}\right)$ and Redwood National Park $\left(41.56^{\circ} \mathrm{N}, 124.09^{\circ} \mathrm{W}\right)$ as part of the Interagency Monitoring of Protected Visual Environments (IMPROVE) network (http://vista.cira.colostate.edu/improve/). Both IMPROVE stations, whose locations are shown in Fig. 1, are less than $5 \mathrm{~km}$ distance from the ocean, and typically experience onshore winds. The IMPROVE stations sample organic carbon particles $<2.5 \mu \mathrm{m}$ in aerodynamic diameter $\left(\mathrm{OC}_{2.5}\right)$ on filters for $24 \mathrm{~h}$ every 3 days to give the average daily concentration in $\mu \mathrm{g} \mathrm{m}^{-3}$. In the model, $\mathrm{OC}_{2.5}$ is the sum of the accumulation mode secondary organic carbon from biogenic and anthropogenic VOCs and the Aitken/accumulation mode primary OC. Table 1 shows that for the entire simulation period (1 June to 31 August 2005) the model tends to overpredict surface $\mathrm{OC}_{2.5}$ concentration for the two coastal sites, and the addition of marine $\mathrm{OC}_{2.5}$ aerosol brings the simulated mean further from the observations. However, careful examination of time series revealed considerable differences between roughly two halves of the simulation period where the first half ( 1 June to 15 July) was characterized by greater contribution of marine $\mathrm{OC}_{2.5}$ to total $\mathrm{OC}_{2.5}$ (Fig. 2). Table 1 shows that during this period with less anthropogenic influence, the inclusion of marine organic emissions improves magnitude and correlation (Redwood only) of the model-predicted $\mathrm{OC}_{2.5}$ concentration for the Point Reyes and Redwood sites. Additional analysis of $\mathrm{OC}_{2.5}$ observations at these sites showed little seasonal variation, which when combined with the relatively steady emission source of marine primary organic aerosol off the Pacific coast indicates that the model improvements from the inclusion of marine organic emissions may occur throughout the year. Our model-predicted marine $\mathrm{OC}_{2.5}$ values over the ocean agree relatively well with summertime OC measurements in areas influenced by open ocean air masses such as Amsterdam Island (Sciare et al., 2009), Mace Head, Ireland (Yoon et al., 2007), the Azores (Pio et al., 2007), and the Northern Atlantic (Russell et al., 2010) which have reported average concentrations of $\sim 0.2,0.4,0.5$, and $0.25 \mu \mathrm{g} \mathrm{m}^{-3}$, respectively.

To assess the accuracy of marine isoprene emissions, the model-predicted ambient isoprene concentrations were compared to observations taken from Photochemical Assessment Monitoring Stations (PAMS) network (http://www. epa.gov/air/oaqps/pams/index.html) located in Ventura, CA $\left(34.28^{\circ} \mathrm{N}, 119.31^{\circ} \mathrm{W}\right)$ and Oceanside, CA $\left(33.22^{\circ} \mathrm{N}\right.$, $117.40^{\circ} \mathrm{W}$ ) on the southern California coast (see Fig. 1). The PAMS stations use gas chromatography-flame ionization de-
Table 2. Comparison of isoprene observations and simulations for two coastal PAMS stations from 1 June to 31 August 2005.

\begin{tabular}{lllll}
\hline Station & $\begin{array}{l}\text { Mean } \\
\text { Obs. }\end{array}$ & $\begin{array}{l}\text { Simulation } \\
(\mathrm{ppb})\end{array}$ & $\begin{array}{l}\text { Mean Sim. } \\
(\mathrm{ppb})\end{array}$ & $\begin{array}{l}\text { Correlation } \\
\text { Coefficient }\end{array}$ \\
\hline Ventura, CA & 0.41 & Baseline & 0.05 & -0.23 \\
& & $\begin{array}{l}\text { Bottom-up } \\
\text { Top-down }\end{array}$ & 0.05 & -0.23 \\
& & 0.08 & -0.24 \\
\hline Oceanside, CA & 0.06 & Baseline & 0.02 & -0.12 \\
& & Bottom-up & 0.03 & -0.13 \\
& & Top-down & 0.03 & -0.14 \\
\hline
\end{tabular}

tector (GC-FID) to measure the instantaneous isoprene concentrations in units of ppb every 6 days several times during the day. The two PAMS stations used for comparison are within $1 \mathrm{~km}$ of the Pacific Ocean. The bottom-up and top-down approaches slightly improve the dramatic underprediction of isoprene concentrations in the baseline simulation at both sites shown in Table 2. However, the addition of marine isoprene emissions does not improve correlations between model predicted and observed concentrations. This is likely due to the uncertainty in the magnitude and mechanisms of marine isoprene emissions and the high detection limit $(0.05 \mathrm{ppbC})$ of isoprene with the GC-FID. Additional uncertainties and potential differences between stations arise from inability to isolate the relatively small marine isoprene emissions from the much larger terrestrial background (Palmer and Shaw, 2005) in the observations, and from the previously-documented consistent disagreement between CMAQ predictions and the PAMS network measurements (Carlton and Reff, 2009).

\subsection{Changes in $\mathbf{O C}_{2.5}$ and $\mathbf{P M}_{2.5}$}

The most substantial air quality effect of marine organic emissions was the increase in $\mathrm{OC}_{2.5}$ concentration. Figure 3 shows that, over the remote ocean, up to $50 \%$ of the $\mathrm{OC}_{2.5}$ concentration can be attributed to the marine sources. This value is consistent with the findings of Russell et al. (2010) who show that $50 \%$ of the Northern Atlantic MBL submicron organic mass $\left(\mathrm{OM}_{1}\right)$ has a marine origin. Figure 3 also demonstrates that, at the coastal areas, a considerable fraction (up to $25 \%$ in certain locations) of $\mathrm{OC}_{2.5}$ aerosol mass can have marine origin. There are also episodic periods where marine sources contribute nearly the entire modelpredicted $\mathrm{OC}_{2.5}$ at the coastal IMPROVE sites (Fig. 2). This is important because the age and chemical evolution of organic aerosols affects their reactivity, hygroscopicity, volatility, and optical properties which can influence both climate forcing and human health (Andreae et al., 2009; Jimenez et al., 2009). The periods of highest marine contribution to model-predicted OC typically occur when concentrations are low, which means that marine organics mainly impact the 


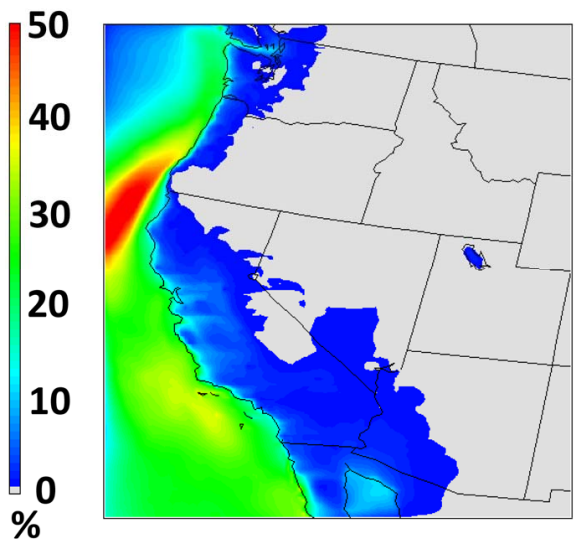

Fig. 3. Average percentage contribution of marine organics to surface $\mathrm{OC}_{2.5}$ concentration for the bottom-up simulation from 1 June to 31 August 2005.

background aerosol concentration. However, even with such large contribution to MBL $\mathrm{OC}_{2.5}$ aerosol mass, marine organic emissions seem to have modest influence on modelpredicted marine $\mathrm{PM}_{2.5}$ which is mostly composed of sea salt. Figure 4a shows that the greatest increase in $\mathrm{PM}_{2.5}$ (over $0.3 \mu \mathrm{g} \mathrm{m}^{-3}$ ) occurs over the ocean near the northern California coast where both $10 \mathrm{~m}$ wind speed (not shown) and ocean biological productivity (see Fig. 1) are high. The spatial distribution of the percentage contribution of marine organic aerosols to average surface $\mathrm{PM}_{2.5}$ concentration (Fig. 4b) is similar to that of the total change in $\mathrm{PM}_{2.5}$ (Fig. 4a), with values up to $10 \%$ near the northern California coast where concentration increases were the highest. The modelpredicted increases and percentage contribution of marine OC to $\mathrm{PM}_{2.5}$ rapidly decrease with distance from the coast to near zero within $\sim 100 \mathrm{~km}$. The gradient of marine contribution to $\mathrm{PM}_{2.5}$ is especially sharp in areas with steep topography. Despite lesser (up to 5\%) percentage contribution to $\mathrm{PM}_{2.5}$ in terrestrial areas with higher concentrations of anthropogenic and biogenic aerosols, marine organic aerosol emissions may still be important for regulatory purposes for the coastal cities like San Francisco, CA that are in nonattainment for the $2006 \mathrm{PM}_{2.5}$ National Ambient Air Quality Standard (NAAQS) (http://www.epa.gov/air/oaqps/greenbk/ pm25_2006_designations_20091113.pdf).

\subsection{Comparison of bottom-up and top-down simulations}

The primary difference between the bottom-up and top-down simulation is the introduction of marine monoterpenes into the model and increased emissions of marine isoprene. These additional emissions result in noticeable changes in the $\mathrm{O}_{3}$ concentration when compared to the bottom-up simulation. Figure 5a shows that for the top-down approach model simulations predict moderate enhancement $(0.5 \%)$ of average
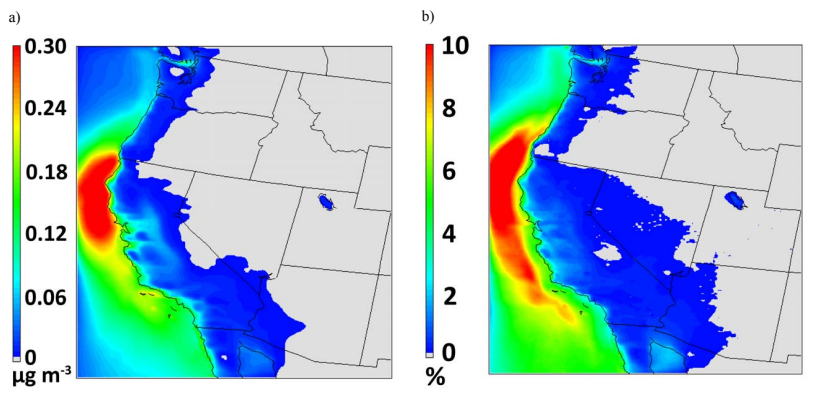

Fig. 4. Average increase (a) and percentage change (b) in surface $\mathrm{PM}_{2.5}$ concentration from marine organics for the bottom-up simulation from 1 June to 31 August 2005.

surface $\mathrm{O}_{3}$ concentration in coastal urban areas and slight decrease $(-0.1 \%)$ in concentration over the remote ocean. The differences between top-down and bottom-up simulations shown on Figs. 5a and $\mathrm{b}$ can be viewed as the high and low estimates of the potential role that marine isoprene and monoterpenes can play in $\mathrm{O}_{3}$ formation near coastal areas. Figures $5 \mathrm{c}$ and d display surface SOA concentration changes due to emissions of marine isoprene and monoterpenes for the top-down and bottom-up simulations, respectively with the maximum increases of $<0.04 \mu \mathrm{g} \mathrm{m}^{-3}$ occurring along the northern California coast where emissions are high. Compared to marine primary organic aerosols, there is a larger inland extent of the marine SOA into areas like the San Joaquin Valley in central California due to the time required for gas-to-particle conversion. These figures show that while the simulated SOA change in top-down approach is considerably higher than that of the bottom-up simulation, the contribution of marine sources of SOA to the total $\mathrm{PM}_{2.5}$ concentrations is an order of magnitude lower compared to the POM marine biogenic sources. The time series of sourceresolved $\mathrm{OC}_{2.5}$ at the IMPROVE sites in Fig. 2 confirms that only at times of very low marine primary OC concentrations are secondary OC concentrations similar in magnitude. Therefore, our model simulations suggest that marine isoprene and monoterpenes contribute a minor fraction of marine OC aerosol mass concentration in near coastal regions. This result is consistent with the modeling and observational studies of Arnold et al. (2009) and Claeys et al. (2009) who show that marine isoprene-SOA makes up a minor portion of fine mode marine OC aerosol mass. It is worth noting that oceanic sources of sulfur (principally DMS) and marine sources of ammonia and amines are not treated by the version of CMAQ model used in the simulations. As marine sources of sulfur, ammonia and alkyamines were shown to be potentially significant contributors to sub-micrometer sized marine aerosol (Charlson et al., 1987; Facchini et al., 2008b; Smith and Mueller, 2010), the reported SOA from marine isoprene and monoterpenes likely represent a low estimate of the total marine secondary OC aerosol. 

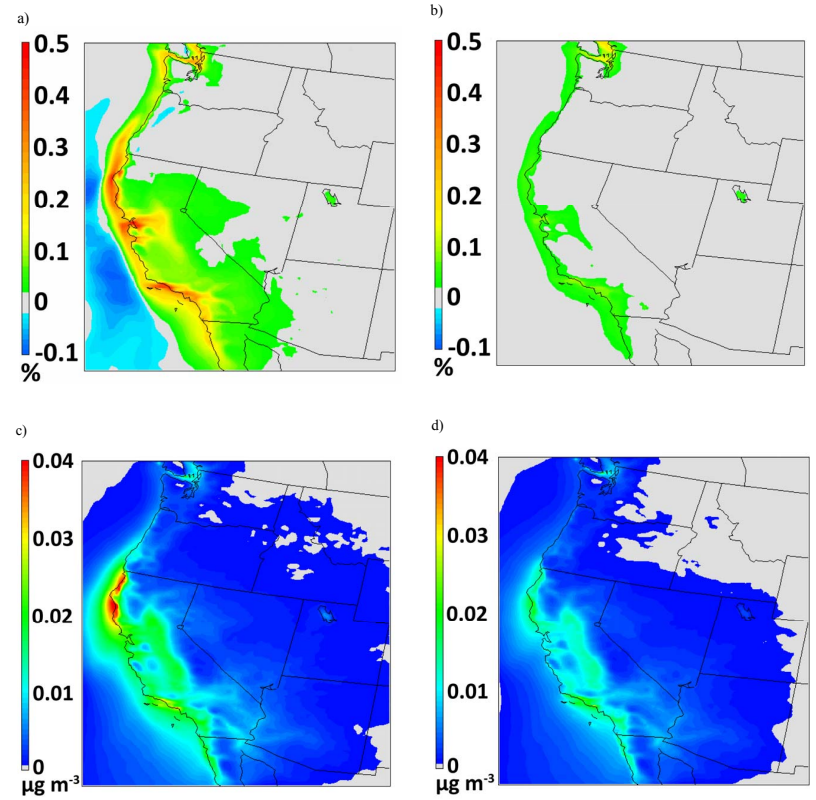

Fig. 5. Average percentage change in surface $\mathrm{O}_{3}$ for the top-down (a) and bottom-up (b) simulations and average increase in surface $\mathrm{SOA}_{2.5}$ concentrations concentration for the top-down (c) and bottom-up (d) simulations due to marine emissions from 1 June to 31 August 2005.

\section{Conclusions}

This is the first study to quantify the combined contribution of marine primary organic aerosol, isoprene, and monoterpene emissions to the air quality of a coastal region. Building on a previous modeling study examining the air quality effect of marine isoprene (Gantt et al., 2010), emissions of marine isoprene, monoterpenes, and primary organic aerosols were implemented in the US EPA's CMAQ model with a domain over the Pacific Ocean and western US. The terrestrial impact of marine organic emissions is strongest at the coast, with average surface $\mathrm{PM}_{2.5}$ and $\mathrm{O}_{3}$ concentrations increasing by up to $5 \%$ and $0.5 \%$, respectively. Further inland, the contribution of marine organic emissions quickly diminishes within $\sim 100 \mathrm{~km}$ of the coast. Over the remote ocean, marine organics contributed over $50 \%$ of the surface $\mathrm{OC}_{2.5}$ and resulted in a $10 \%$ change in $\mathrm{PM}_{2.5}$ concentrations. The source of additional $\mathrm{PM}_{2.5}$ in the simulations is dominated by POM, with the SOA source from isoprene and monoterpenes making up a much smaller portion of the $\mathrm{PM}_{2.5}$ mass. Model calculations indicate that during periods of high marine organic aerosol contribution, the inclusion of marine organic emissions can yield improved model predictions of surface $\mathrm{OC}_{2.5}$ concentration at the California coast. The addition of isoprene and monoterpenes from marine sources did not have considerable effect on $\mathrm{O}_{3}$ or SOA surface concentration in coastal areas. For surface isoprene concentrations measured at the southern California coast, the large under- prediction by the model is slightly improved by the additional marine isoprene emissions. This study suggests that marine organic aerosols account for a considerable portion of the aerosol mass over the remote ocean and some nearcoastal regions and, therefore needs to be considered in future air quality models. The subsequent health impacts of marine organics may be underestimated by these results, as studies have shown that the organic mass fraction of marine aerosols is particularly large for particles $<0.125 \mu \mathrm{m}$ in diameter (O'Dowd et al., 2004). Furthermore, organic vapors from marine sources of VOC have been implicated to aid nucleation events and growth of ultrafine particles in coastal environments, potentially producing large numbers of particles at sizes problematic for human health (Vaattovaara et al., 2006; Modini et al., 2009). While this modeling study shows a small contribution of marine isoprene and monoterpeneSOA to total OC aerosol mass over the ocean, a number of important sources of marine-SOA from biogenic amines and methanesulfonate were not included in the current CMAQ simulations. Additional field measurements and model simulations with improved aerosol size/chemical characterization and emission source functions may be necessary to fully explore the significance of marine organic aerosol and biogenic trace gas emissions on coastal air quality and human health.

Acknowledgements. This research was supported by the Office of Science (BER), US Department of Energy, Grant No. DE-FG0208ER64508. Thanks to Kirk Baker of the US EPA/OAQPS for providing the meteorological fields, emission inventories, initial and boundary conditions for the baseline simulations. Although this paper has been reviewed by EPA and approved for publication, it does not necessarily reflect EPA's policies or views.

Edited by: M. Kanakidou

\section{References}

Andreae, M. O: A new look at aging aerosols, Science, 326(5959), 1493-1494, doi:10.1126/science.1183158, 2009.

Arnold, S. R., Spracklen, D. V., Williams, J., Yassaa, N., Sciare, J., Bonsang, B., Gros, V., Peeken, I., Lewis, A. C., Alvain, S., and Moulin, C.: Evaluation of the global oceanic isoprene source and its impacts on marine organic carbon aerosol, Atmos. Chem. Phys., 9, 1253-1262, doi:10.5194/acp-9-1253-2009, 2009.

Atkinson, R. and Arey, J.: Atmospheric chemistry of biogenic organic compounds, Accounts Chem. Res., 31, 574-583, 1998.

Bigg, E. K.: Sources, nature and influence on climate of marine airborne particles, Environ. Chem., 4, 155-161, doi:10.1071/EN07001, 2007.

Bigg, E. K. and Leck, C.: The composition of fragments of bubbles bursting at the ocean surface, J. Geophys. Res., 113 (D1), 1209, doi:10.1029/2007JD009078, 2008.

Blanchard, D. C. and Woodcock A. H.: Bubble formation and modification in the sea and its meteorological significance, Tellus, 9, 145-158, 1957.

Bonsang, B., Polle, C., and Lambert, G.: Evidence for marine production of isoprene, Geophys. Res. Lett., 19, 1129-1132, 1992. 
Carlton, A. G. and Reff, A.: Assessment of CMAQ-predicted SOA precursor concentrations, American Association for Aerosol Research (AAAR) Annual Conference, Minneapolis, MN, Nov. 2009.

Carlton, A. G., Bhave, P. V., Napelenok, S. L., Edney, E. O.; Sarwar, G., Pouliot, G. A., and Houyoux M.: Model representation of secondary organic aerosol in CMAQv4.7, Environ. Sci. Technol., accepted, 2010.

Ceburnis D., O’Dowd, C., Jennings, G. S., Facchini, M. C., Emblico, L., Decesari, S., Fuzzi, S., and Sakalys, J.: Marine aerosol chemistry gradients: Elucidating primary and secondary processes and fluxes, Geophys. Res. Lett., 35, L07804, doi:10.1029/2008GL033462, 2008.

Charlson, R. J., Lovelock J. E., Andreae M. O., and Warren S. G.: Oceanic phytoplankton, atmospheric sulfur, cloud albedo and climate, Nature, 326, 655-661, 1987.

Chavez, F. P., Barber, R. T., Kosro, P. M., Huyer, A., Ramp, S. R., Stanton, T. P., and Rojas de Mendiola, B.: Horizontal transport and the distribution of nutrients in the coastal transition zone off Northern California: effects on primary production, phytoplankton biomass and species composition. J. Geophys. Res., 96 (C8), 14833-14848, 1991.

Claeys, M. B., Wang, W., Vermeylen, R., Kourtchev, I., Chi, X., Farhat, Y. J., Surratt, D., Gómez-González, Y., Sciare, J., and Maenhaut, W.: Chemical characterisation of marine aerosol at Amsterdam Island during the austral summer of 2006-2007, J. Aero. Sci., 41(1), 13-22, doi:10.1016/j.jaerosci.2009.08.003, 2009.

Colomb, A., Gros, V., Alvain, S., Sarda-Esteve, R., Bonsang, B., Moulin, C., Klüpfel, T., Williams, J.: Variation of atmospheric volatile organic compounds over the Southern Indian Ocean (30-49 S), Environ. Chem., 6(1), 70-82, doi:10.1071/EN08072, 2009.

De Bruyn, W. J. and Saltzman E. S.: Diffusivity of methyl bromide in water, Mar. Chem., 57, 55-59, 1997.

Decesari, S., Facchini, M. C., Mircea, M., Cavalli, F., Emblico, L., Fuzzi, S., Moretti, F., and Tagliavini, E.: Source attribution of water-soluble organic aerosol by nuclear magnetic resonance spectroscopy, Environ. Sci. Technol., 41, 2479-2484, 2007.

de Leeuw, G., Neele, F. P., Hill, M., Smith, M. H., and Vignati, E.: Production of sea spray aerosol in the surf zone, J. Geophys. Res., 105, 29397-29409, 2000.

Donaldson, D. J. and Vaida, V.: The influence of organic films at the air-aqueous boundary on atmospheric processes, Chem. Rev., 106 (4), 1445-1461, 2007.

Facchini, M. C., Rinaldi, M., Decesari, S., Carbone, C., Finessi, E., Mircea, M., Fuzzi, S., Ceburnis, D., Flanagan, R., Nilsson, E. D., de Leeuw, G., Martino, M., Woeltjen, J., and O'Dowd, C. D.: Primary submicron marine aerosol dominated by insoluble organic colloids and aggregates, Geophys. Res. Lett., 35, L17814, doi:10.1029/2008GL034210, 2008a.

Facchini, M. C., Decesari, S., Rinaldi, M., Carbone, C., Finessi, E., Mircea, M., Fuzzi, S., Moretti, F., Tagliavini, E., Ceburnis, D., and O'Dowd, C. D.: Important source of marine secondary organic aerosol from biogenic amines, Environ. Sci. Technol., 42, 9116-9121, 2008b.

Galbally, I. E., Lawson, S. J., Weeks, I. A., Bentley, S. T., Gillett, R. W., Meyer, M., and Goldstein, A. H.: Volatile organic compounds in marine air at Cape Grim, Australia, Environ. Chem.,
4(3), 178-182, doi:10.1071/EN07024, 2007.

Gantt, B., Meskhidze, N., and Kamykowski, D.: A new physically-based quantification of marine isoprene and primary organic aerosol emissions, Atmos. Chem. Phys., 9, 4915-4927, doi:10.5194/acp-9-4915-2009, 2009.

Gantt, B., Meskhidze, N., Zhang, Y., and Xu, J.: The effect of marine isoprene emissions on secondary organic aerosol and ozone formation in the coastal United States, Atmos. Environ., 44, 115$121,2010$.

Gong, S. L.: A parameterization of sea-salt aerosol source function for sub- and super- micron particles, Global Biogeochem. Cy., 17(4), 1097, doi:1029/2003GB002079, 2003.

Grell, G. A., Dudhia, J., and Stauffer, D. R. A.: A description of the Fifth Generation Penn 15 State/NCAR Mesoscale Model (MM5), NCAR Technical Note, 1994, NCAR/TU-398+STR, 138, 1994.

Guenther, A., Baugh, W., Zimmerman, P., Klinger, L., Harley, P., Westberg, H., Vierling, L., Lamb, B., Allwine, E., Dilts, S., Baldocchi, D., Geron, C., and Pierce, T.: Isoprene fluxes measured by enclosure, relaxed eddy accumulation, surface-layer gradient, mixed-layer gradient, and mass balance techniques, J. Geophys. Res., 101, 18555-18568, 1996.

Hawkins L. N. and Russell, L. M.: Polysaccharides, proteins, and phytoplankton fragments: Four chemically distinct types of marine primary organic aerosol classified by single particle spectromicroscopy, 612132, doi:10.1155/2010/612132, 2010.

Hoffman, E. J. and Duce, R. A.: Factors influencing the organic carbon content of marine aerosols: A laboratory study, J. Geophys. Res., 81(21), 3667-3670, 1976.

Jimenez, J., Canagaratna, M. R., Donahue, N. M, et al.: Evolution of organic aerosols in the atmosphere, Science, 326(5959), 1525-1529, doi:10.1126/science.1180353, 2009.

Keene, W. C., Maring, H., Maben, J. R., Kieber, D. J., Pszenny, A. A. P., Dahl, E. E., Izaguirre, M. A., Davis, A. J., Long, M. S., Zhou, X. L., Smoydzin, L., and Sander, R.: Chemical and physical characteristics of nascent aerosols produced by bursting bubbles at a model air-sea interface, J. Geophys. Res., 112, D21202, doi:10.1029/2007JD008464, 2007.

Kelly, J. T., Bhave, P. V., Nolte, C. G., Shankar, U., and Foley, K. M.: Simulating emission and chemical evolution of coarse seasalt particles in the Community Multiscale Air Quality (CMAQ) model, Geosci. Model Dev., 3, 257-273, doi:10.5194/gmd-3257-2010, 2010.

Modini, R. L., Ristovski, Z. D., Johnson, G. R., He, C., Surawski, N., Morawska, L., Suni, T., and Kulmala, M.: New particle formation and growth at a remote, sub-tropical coastal location, Atmos. Chem. Phys., 9, 7607-7621, doi:10.5194/acp-9-7607-2009, 2009.

Leck, C. and Bigg, E. K.: Comparison of sources and nature of the tropical aerosol with the summer high Arctic aerosol, Tellus, 60B, 118-126, doi:10.1111/j.1600-0889.2007.00315.x, 2008.

Lewis, E. R. and Schwartz S. E.: Sea Salt Aerosol Production: Mechanisms, Methods, Measurements, and Models, American Geophysical Union, Washington, DC, 2004.

Liakakou, E., Vrekoussis M., Bonsang B., Donousis C., Kanakidou M., and Mihalopoulos N.: Isoprene above the Eastern Mediterranean: Seasonal variation and contribution to the oxidation capacity of the atmosphere, Atmos. Environ., 41(5), 1002-1010, doi:10.1016/j.atmosenv.2006.09.034, 2007. 
Luo, G. and Yu, F.: A numerical evaluation of global oceanic emissions of $\alpha$-pinene and isoprene, Atmos. Chem. Phys., 10, 20072015, doi:10.5194/acp-10-2007-2010, 2010.

O’Dowd, C., Jimenez, J., Bahreini, R., Flagan, R., Seinfeld, J., Hämeri, K., Pirjola, L., Kulmala, M., Jennigns, S., and Hoffmann, T.: Marine aerosol formation from biogenic iodine emissions, Nature, 417, 632-636, 2002.

O’Dowd, C. D., Facchini M. C., Cavalli F., Ceburnis, D., Mircea, M., Decesari, S., Fuzzi, S., Yoon, Y. J., and Putaud, J. P.: Biogenically driven organic contribution to marine aerosol, Nature, 431, 676-680, 2004.

O'Dowd, C. D. and de Leeuw, G.: Marine aerosol production: a review of the current knowledge, Phil. Trans. R. Soc. A, 365, 1753-1774, 2007.

O’Dowd, C. D., Langmann, B., Varghese S., Scannell, C., Ceburnis, D., and Facchini, M. C.: A combined organic-inorganic sea-spray source function, Geophys. Res. Lett., 35, L01801, doi:10.1029/2007GL030331, 2008.

Palmer, P. I. and Shaw, S. L.: Quantifying global marine isoprene fluxes using MODIS chlorophyll observations, J. Geophys. Res., 32, L09805, doi:10.1029/2005GL022592, 2005.

Park, R. J., Jacob, D. J., Field, B. D., Yantosca, R. M., and Chin, M.: Natural and transboundary pollution influences on sulfatenitrate-ammonium aerosols in the United States: implications for policy, J. Geophys. Res., 109, D15204, 10.1029/2003JD004473, 2004.

Pio, C. A., Legrand, M., Oliveira, T., Afonso, J., Santos, C., Caseiro, A., Fialho, P., Barata, F., Puxbaum, H., Sanchez-Ochoa, A., Kasper-Giebl, A., Gelencser, A., Preunkert, S., and Schock, M.: Climatology of aerosol composition (organic versus inorganic) at nonurban sites on a west-east transect across Europe, J. Geophys. Res., 112, D23S02, doi:10.1029/2006JD008038, 2007.

Rinaldi, M., Decesari, S., Finessi, E., Guilianelli, L., Carbone, C., Fuzzi, S., O'Dowd, C., Ceburnis, D., and Facchini, M.C.: Primary and secondary organic marine aerosol and oceanic biological activity: recent results and new perspectives for future studies, Advances Meteorol., 310682, doi:10.1155/2010/310682, 2010 .
Russell, L. M., Hawkins, L. N., Frossard, A. A., Quinn, P. K., and Bates, T. S.: Carbohydrate-like composition of submicron atmospheric particles and their production from ocean bubble bursting, Proc. Nat. Acad. Sci., 107, 6652-6657, doi:10.1073/pnas.0908905107, 2010.

Sciare, J., Favez, O., Sarda-Estève, R., Oikonomou, K., Cachier, H., and Kazan, V.: Long-term observations of carbonaceous aerosols in the Austral Ocean atmosphere: Evidence of a biogenic marine organic source, J. Geophys. Res., 114, D15302, doi:10.1029/2009JD011998, 2009.

Sellegri, K., Villani, P., Picard, D., Dupuy, R., O'Dowd, C., and Laj, P.: Role of the volatile fraction of submicron marine aerosol on its hygroscopic properties, Atmos. Res., 90, 2-4, 272-277, doi: 10.1016/j.atmosres.2008.04.004, 2008.

Shaw G. E.: Bio-controlled thermostasis involving the sulfur cycle, Clim. Change, 5, 297-303, 1983.

Smith, S. N. and Mueller, S. F.: Modeling natural emissions in the Community Multiscale Air Quality (CMAQ) ModelI: building an emissions data base, Atmos. Chem. Phys., 10, 4931-4952, doi:10.5194/acp-10-4931-2010, 2010.

Vaattovaara, P., Huttunen, P. E., Yoon, Y. J., Joutsensaari, J., Lehtinen, K. E. J., O'Dowd, C. D., and Laaksonen, A.: The composition of nucleation and Aitken modes particles during coastal nucleation events: evidence for marine secondary organic contribution, Atmos. Chem. Phys., 6, 4601-4616, doi:10.5194/acp-64601-2006, 2006.

Wanninkhof, R.: Relationship between wind speed and gas exchange over the ocean, J. Geophys. Res., 97, 7373-7382, 1992.

Yassaa, N., Peeken, I., Zöllner, E., Bluhm, K., Arnold, S., Spracklen, D., and Williams, J.: Evidence for marine production of monoterpenes, Environ. Chem., 5, 391-401, doi:10.1071/EN08047, 2008.

Yoon, Y. J., Ceburnis, D., Cavalli, F., et al.: Seasonal characteristics of the physiochemical properties of North Atlantic marine atmospheric aerosols, J. Geophys. Res., 112, D04206, doi:10.1029/2005JD007044, 2007. 